\title{
Application of small fragment restriction endonuclease analysis (SF-REA) to the epidemiological fingerprinting of Staphylococcus aureus
}

\author{
R. HAERTL and G. BANDLOW
}

Staatliches Medizinaluntersuchungsamt Osnabrueck, Alte Poststrasse 11, D-4500 Osnabrueck, FederalRepublic of Germany

\begin{abstract}
Summary. Total cell DNA of 14 isolates of Staphylococcus aureus from patients of an intensive care unit (ICU) and 180 unrelated strains was examined by restriction endonuclease analysis (REA). EcoRI-generated DNA fragments were either subjected to conventional REA on agarose gels and stained with ethidium bromide or separated by polyacrylamide gel electrophoresis and visualised by silver staining (SF-REA). Both methods were compared for inter-strain discriminatory ability, reproducibility and handling. All DNA-cleavage patterns of unrelated strains clearly differed from each other when subjected to SF-REA. In contrast, all $S$. aureus isolates from the ICU gave identical restriction fragment patterns. These findings supported the suspicion of nosocomial infection in these patients. Conventional REA proved the identity of the ICU isolates, but it failed to differentiate between some of the unrelated strains. Therefore SF-REA of total cell DNA seemed to be superior. It has proved to be a very useful technique for studying the epidemiology of $S$. aureus in hospitals.
\end{abstract}

\section{Introduction}

Epidemiological investigations and analysis of nosocomial outbreaks of Staphylococcus aureus infection often are hampered by the relatively poor discriminatory properties of conventional marker systems such as antibiograms, phage typing, and plasmid profile analysis. Immunoblotting techniques seem promising, but they have some disadvantages: their reproducibility is linked to standardised antibody probes ${ }^{1}$ and they recognise phenotypic rather than genomic characters.

We report the use of restriction enzyme digests of total cell DNA to recognise polymorphisms in restriction fragment lengths. In particular, the analysis of small fragments within the cleavage patterns may be a useful method for typing $S$. aureus isolates.

Restriction endonuclease analysis (REA) has been applied successfully to investigate phenotypically closely related strains of Borrelia burgdorferi, ${ }^{2}$ Mycobacterium sp., ${ }^{3}$ Pseudomonas aeruginosa, ${ }^{4} \mathrm{Vi}$ brio cholerae, ${ }^{5}$ Legionella pneumophila, ${ }^{6}$ Helicobacter pylori ${ }^{7}$ Neisseria gonorrhoeae ${ }^{8} N$. meningitidis, ${ }^{9}$ Clostridium difficile, ${ }^{10}$ group B streptococci, ${ }^{11}$ Staphylococcus epidermidis ${ }^{12}$ and even $S$. aureus. ${ }^{13}$ Separation of restriction fragments is mostly per-

Received 11 Jan. 1990; accepted 22 March 1990. formed by agarose gel techniques. These procedures are often time-consuming. Furthermore they depend on restriction enzymes which cut rarely and generate relatively large fragments, because small and very small fragments cannot be well resolved. It is difficult and sometimes impossible to evaluate small DNA-fragment patterns on agarose gels when outstanding markers or differences among the larger fragments cannot be detected. Employing polyacrylamide gel electrophoresis (PAGE) and silver staining we established a rapid and sensitive method for generating strain-specific, reproducible, well focused, and durable restriction patterns of small DNA fragments.

\section{Materials and methods}

\section{Bacterial strains}

Staphylococci were isolated from clinical samples submitted routinely to our diagnostic laboratory. S. aureus was identified by conventional methods. ${ }^{14}$ Of 194 strains examined, 14 were isolated from blood cultures, central venous catheters, tracheal aspirates and surgical wound swabs from seven patients in an ICU of one hospital (for details see table); 180 epidemiologically unrelated $S$. aureus isolates from patients of 15 different hospitals, including the one where the outbreak occurred, were collected over a period of 4 months. All strains were 
Table. $S$. aureus isolates from the ICU

\begin{tabular}{|c|c|c|c|}
\hline $\begin{array}{c}\text { Sample } \\
\text { no. }\end{array}$ & $\begin{array}{l}\text { Date of } \\
\text { isolation }\end{array}$ & Patient & Sample \\
\hline 1 & $05 / 22 / 89$ & A & Surgical wound \\
\hline 2 & $05 / 22 / 89$ & B & Penis swab \\
\hline 3 & $05 / 22 / 89$ & B & Tracheal aspirate \\
\hline 4 & $05 / 22 / 89$ & $\mathrm{C}$ & Tracheal aspirate \\
\hline 5 & $05 / 23 / 89$ & B & Central venous catheter \\
\hline 6 & $05 / 23 / 89$ & $\mathrm{C}$ & Central venous catheter \\
\hline 7 & $05 / 24 / 89$ & D & Central venous catheter \\
\hline 8 & $05 / 25 / 89$ & B & Tracheal aspirate \\
\hline 9 & $05 / 29 / 89$ & B & Surgical wound \\
\hline 10 & $05 / 29 / 89$ & B & Tracheal aspirate \\
\hline 11 & $06 / 05 / 89$ & $\mathrm{C}$ & Tracheal aspirate \\
\hline 12 & $06 / 27 / 89$ & $\mathrm{E}$ & Blood culture \\
\hline 13 & $06 / 27 / 89$ & $\mathbf{F}$ & Surgical wound \\
\hline 14 & $06 / 28 / 89$ & G & Blood culture \\
\hline
\end{tabular}

isolated by plating the samples on sheep blood agar. A single colony was grown overnight in $200 \mathrm{ml}$ of Tryptone Soya Broth (Oxoid, CM129) at $36^{\circ} \mathrm{C}$, harvested by centrifugation at $5000 \mathrm{~g}$, washed twice in Tris-EDTA buffer, $\mathrm{pH} 8.0$ (10 mM Tris-HCl, $1 \mathrm{~mm}$ disodium-EDTA), and stored at $-20^{\circ} \mathrm{C}$ until tested.

\section{Antibiograms}

Antimicrobial susceptibility was determined by the disk diffusion method on Antibiotic-SulphonamideSensitivity-Test Agar (Merck, 5392) with overnight incubation at $36^{\circ} \mathrm{C} .{ }^{15}$ The following antimicrobial agents were tested $(\mu \mathrm{g} / \mathrm{disk})$ : penicillin $(10)$, oxacillin (1), ampicillin (10), cephazolin (30), cefuroxime (30), cefoxitin (30), cefotaxime (30), cefaclor (30), gentamicin (10), amikacin (10), tetracycline (30), chloramphenicol (30), co-trimoxazole (25), ofloxacin (5), ciprofloxacin (5), erythromycin (15) and clindamycin (10).

\section{DNA isolation}

Total cell DNA was extracted from $300 \mu$ l of packed cells. Staphylococci were lysed by a modification of the procedure described by Harstein et al. ${ }^{16}$ Briefly, cells were suspended in $2 \mathrm{ml}$ of lysostaphin buffer $(2.5 \mathrm{M} \mathrm{NaCl}$, $10 \mathrm{~mm}$ disodium-EDTA, pH 8.0) and $50 \mu \mathrm{l}$ of lysostaphin $1 \mathrm{mg} / \mathrm{ml}$ in Tris-EDTA buffer, $\mathrm{pH} 8.0$ (Sigma, 7386) was added. After incubation for $60 \mathrm{~min}$ at $37^{\circ} \mathrm{C}$, lysis was achieved by adding of $12 \mathrm{ml}$ of lysing solution [dodecyltrimethylammonium bromide (Sigma, D-8638) $0.5 \%+$ Triton X-100 (Serva, 37240) $0.25 \%$ ]. The tubes were mixed gently and incubated for $15 \mathrm{~min}$ at $56^{\circ} \mathrm{C}$. Mixtures were then extracted twice with $15 \mathrm{ml}$ of phenol: chloroform $(1: 1, v: v)$. DNA from the upper phase was precipitated with an equal volume of isopropanol, washed in ethanol $70 \%$, dissolved in $300 \mu$ l of Tris-EDTA buffer, $\mathrm{pH} 7 \cdot 5$, and stored at $4^{\circ} \mathrm{C}$.

\section{Restriction endonuclease digestions}

DNA $(5 \mu \mathrm{g})$ was completely digested in a reaction mixture containing a 10 -fold excess of EcoRI (New England Biolabs, Inc., 101) in EcoRI buffer (50 mM $\mathrm{NaCl}, 100 \mathrm{mM}$ Tris- $\mathrm{HCl}, \mathrm{pH} 7 \cdot 5,5 \mathrm{mM} \mathrm{MgCl}_{2}$, bovine serum albumin $100 \mu \mathrm{g} / \mathrm{ml}$ ) at $37^{\circ} \mathrm{C}$ for $2 \mathrm{~h}$. Digestions were terminated by adding an equal volume of gel loading buffer (Ficoll $40015 \% \mathrm{w} / \mathrm{v}+$ Orange $\mathrm{G} 0.05 \% \mathrm{w} / \mathrm{v}$ in $10 \mathrm{~mm}$ disodium-EDTA, $\mathrm{pH} \mathrm{8.0)}$.

\section{Polyacrylamide gel electrophoresis}

PAGE was performed on an SE 250 Mighty Small II, 7-cm Vertical Dual Slab Unit (Hoefer Scientific Instruments, San Francisco, CA, USA). The gels were cast in an SE 215 Mighty Small Multiple Gel Caster. Eight gels $(0.75-\mathrm{mm}$ thick) were prepared at once from an acrylamide $30 \%$-bis-acrylamide $1.6 \%$ stock solution (Serva, 10675 and 29195$)$ in TBE buffer $(0.09 \mathrm{M}$ Tris, $0.09 \mathrm{M}$ boric acid, $0.002 \mathrm{M}$ disodium-EDTA, $\mathrm{pH} 8.3$ ). Before samples were loaded the slots were rinsed twice with tank buffer. Cells were then loaded with $1-20 \mu$ of DNA digest. The gels were run at $18 \mathrm{~mA}$ constant current for $60 \mathrm{~min}$ in TBE buffer.

\section{Agarose gel electrophoresis}

DNA fragments were separated by electrophoresis on horizontal agarose $0.7 \%$ gels (Serva, 11404) for $20 \mathrm{~h}$ at $40 \mathrm{~V}$ in TBE buffer. Gels were stained with ethidium bromide $1 \mu \mathrm{g} / \mathrm{ml}$ for $30 \mathrm{~min}$, briefly rinsed in water, and photographed under UV illumination. Phage $\lambda$ DNA $B s t$ EII digest (New England Biolabs, Inc., 301-4) served as a molecular size standard.

\section{Silver staining}

Polyacrylamide gels were stained by a modification of the silver staining procedure of Tsang et al. ${ }^{17}$ The gels were treated successively with aqueous trichloroacetic acid $10 \%$ for $15 \mathrm{~min}$ and ethanol: acetic acid: distilled water $(20: 5: 75 \mathrm{v}: \mathrm{v}: \mathrm{v})$ for $15 \mathrm{~min}$. To clear up the background they were incubated for $5 \mathrm{~min}$ in aqueous potassium dichromate $0.5 \%$ solution and then rinsed three times with distilled water. Impregnation was performed in aqueous silver nitrate $0.1 \%$ solution for $10 \mathrm{~min}$. After rinsing twice with water, colour was developed in an aqueous mixture of sodium carbonate $3 \%$ supplemented with paraformaldehyde $0.002 \%$. The colour reaction was terminated by a short rinse with distilled water and addition of $100 \mathrm{ml}$ of acetic acid $1 \%$. Gels were stored in the same solution. They were stable for months without any loss of colour when kept in the dark.

\section{Results}

DNA extraction, restriction endonuclease digestion, and electrophoresis in polyacrylamide $5 \%$ gels 
of 194 clinical isolates of $S$. aureus revealed clear gel patterns, consisting of multiple bands, varying in intensity and number. About 40 bands were identified after $E c o$ RI digestion. All isolates were typable by this method. Unrelated $S$. aureus strains displayed a marked degree of polymorphism, particularly evident in the small fragments. Fig. 1 shows typical results of EcoRI DNA digests from epidemiologically unrelated $S$. aureus strains. Isolates 1-13 had identical antibiotic susceptibility profiles. They were resistant to penicillin and ampicillin, but sensitive to all other antimicrobial agents tested. Track 14 shows the DNA cleavage pattern of the epidemic strain from the ICU.

Fragments of $1000-4000 \mathrm{bp}$ were well separated in polyacrylamide gels, yielding sufficient information for reliable identification of each isolate. The cleavage patterns of unrelated isolates clearly differed from each other. Each isolate produced its own unique "fingerprint". The cleavage patterns show a broad band in the upper third of the gel, containing large restriction fragments which cannot be resolved by polyacrylamide gel electrophoresis. They could be separated sufficiently, when subjected to electrophoresis in agarose $0.7 \%$ gels.

The method gave good reproducibility; three EcoRI digests performed on separate DNA extractions of the same strain produced identical restriction-fragment patterns, and even after 1, 20, 40 and 60 subcultures of a single strain, all EcoRI generated
DNA cleavage patterns were identical, when electrophoresed on the same gel, confirming genetic stability of the clone examined.

These findings convinced us that SF-REA may be useful in investigating the transmission and acquisition of $S$. aureus within small human population groups and cohorts, such as hospitalised patients in wards and ICUs. Fourteen $S$. aureus isolates from clinical samples of seven patients from an ICU were collected over a 5-week period. In two cases $S$. aureus was isolated repeatedly from the same patients. All isolates were resistant to penicillin, ampicillin, gentamicin, amikacin, tetracycline, chloramphenicol, co-trimoxazole, ofloxacin, ciprofloxacin and erythromycin, but sensitive to oxacillin, cephazolin, cefuroxime, cefoxitin, cefotaxime and clindamycin; 10 isolates were resistant to cefaclor.

Fig. 2 shows the $E c o$ RI-generated DNA-cleavage patterns of the $14 S$. aureus isolates from the ICU. Nodifferences between these isolates were detected, suggesting that all isolates were genetically identical and of common origin. With REA on agarose $0.7 \%$ gels, all isolates from the ICU also gave identical EcoRI restriction-fragment patterns, confirming the results of SF-REA, but considerable difficulties occurred in evaluating the profiles of unrelated strains. Because there were no outstanding markers within the relatively small number of well-focused bands of some profiles, restriction-fragment pat-

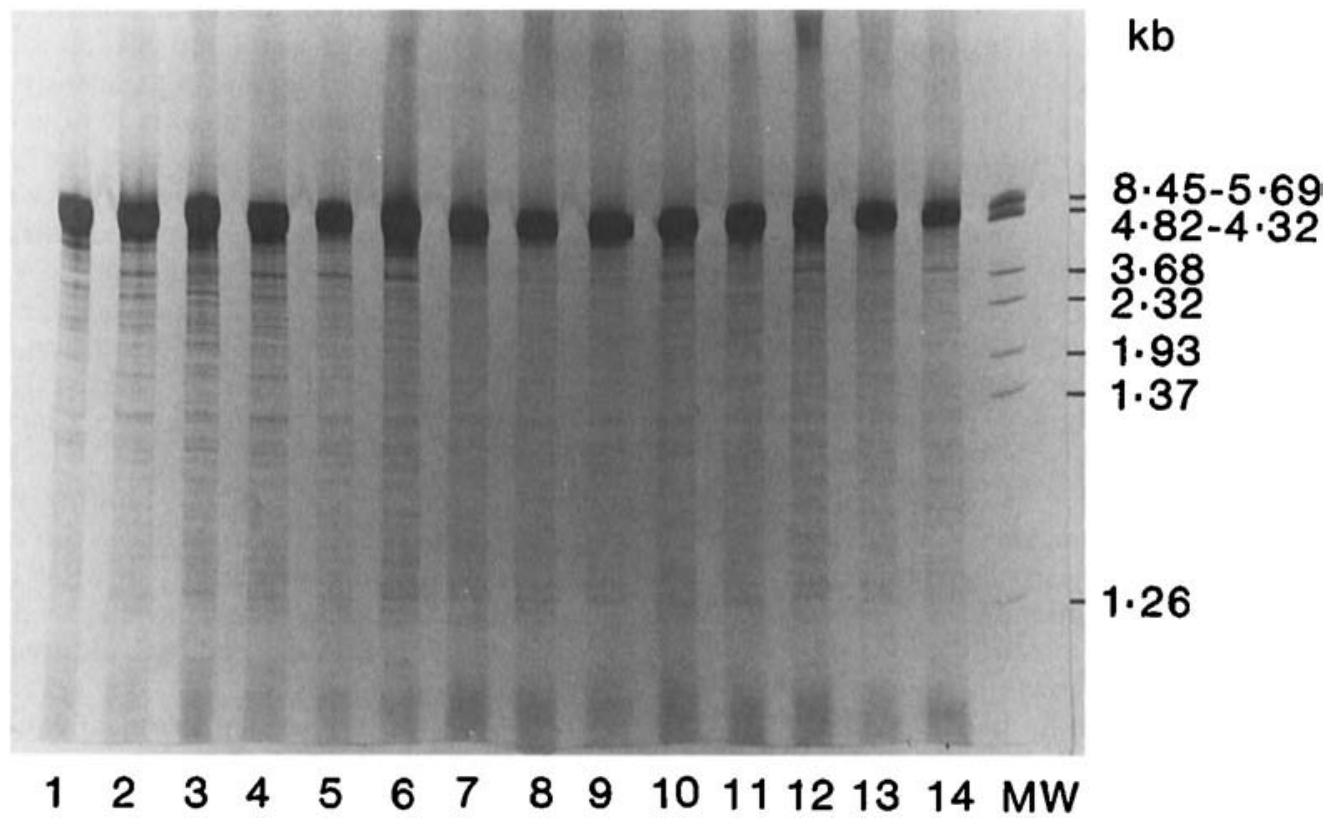

Fig. 1. EcoRI digested $S$. aureus DNA after electrophoresis in polyacrylamide $5 \%$ gel and silver staining. Tracks $1-13$, unrelated strains; 14 , epidemic strain from the ICU; MW, phage $\lambda$ DNA, BstEII digest. 


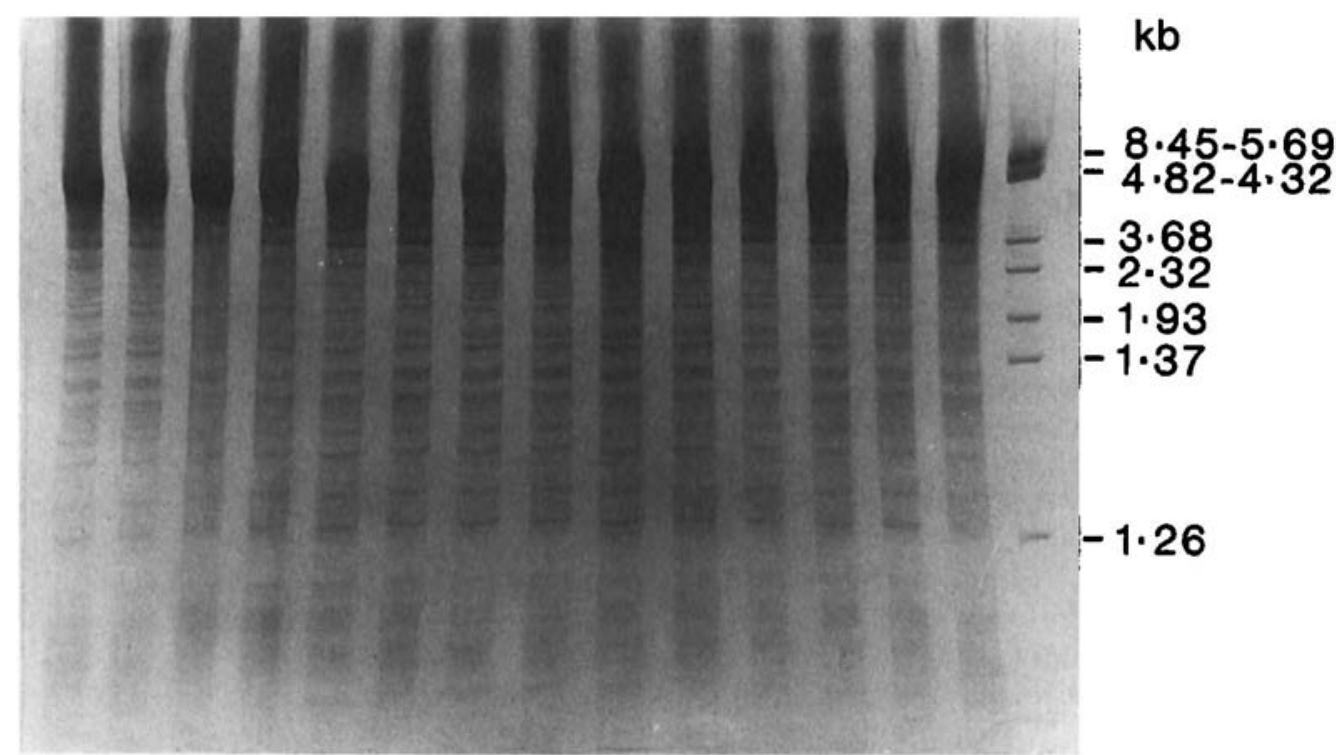

\section{$\begin{array}{lllllllllllllll}1 & 2 & 3 & 4 & 5 & 6 & 7 & 8 & 9 & 10 & 11 & 12 & 13 & 14 & \mathrm{MW}\end{array}$}

Fig. 2. EcoRI digested $S$. aureus DNA after electrophoresis in polyacrylamide $5 \%$ gel and silver staining. Tracks $1-14$, isolates from the ICU (track number corresponds to sample number in table); MW, phage $\lambda$ DNA, BstEII digest.

terns looked rather similar. Therefore, reliable discrimination of these unrelated isolates by conventional REA was not possible.

\section{Discussion}

Antibiotic susceptibility testing, phage typing, and plasmid-pattern analysis have been standard methods for examining relatedness among $S$. aureus isolates. The antibiogram has proved to be useful in epidemiological studies, but it is often unstable and closely linked to the plasmid content. ${ }^{18}$ Unfortunately, phage typing is available only at a few centres. Recourse to a reference laboratory takes time and, therefore, does not allow the rapid instigation of control measures. Even using the international set of phages as amended by the International Subcommittee of Phage-typing of $S$. aureus in $1975,27-75 \%$ of epidemic $S$. aureus isolates remain untypable ${ }^{19,20}$ at RTD and 100 RTD. Plasmid analysis seems to be superior in some cases, ${ }^{21}$ but it depends on the presence of episomal DNA. Harstein et al. ${ }^{16}$ reported that $34 \%$ of the $S$. aureus isolates examined in their study did not have any detectable plasmid DNA. Even immunoblot fingerprinting as a phenotype-based typing system has some disadvantages. It depends strongly on the antiserum used for the detection of staphylococcal antigens and cannot be easily stan- dardised for general use. Antigenic variability also may render the interpretation of results more difficult. ${ }^{22}$

The results of this study clearly demonstrate that SF-REA of total cell DNA can be used as a reliable technique to identify $S$. aureus strains. The ability to distinguish between unrelated isolates makes SFREA a useful tool for examining transmission and acquisition of $S$. aureus strains within human populations. Burnie et $a .^{22}$ reported the relatively low inter-strain discriminatory ability of whole cell REA performed in agarose gels in comparison with immunoblot fingerprinting. This finding was confirmed by our results. With polyacrylamide gel electrophoresis, a much higher resolution of small fragments is achieved than in agarose gels. The large number of well-focused bands can be used for more reliable strain discrimination that does not depend on the presence of outstanding markers, which may be absent. These qualities convinced us of the discriminatory superiority of SR-REA over conventional REA. We employed SF-REA to detect and confirm a nosocomial outbreak of $S$. aureus infection in an ICU.

As demonstrated, epidemiologically unrelated strains, with identical antibiograms, were clearly distinguished by this method. Although large fragments were not resolved in polyacrylamide gels, the analysis of small cleavage fragments of 1000 
$4000 \mathrm{bp}$ yielded sufficient information for reliable discrimination of all isolates examined. In contrast, all isolates from an ICU of one hospital exhibited identical EcoRI DNA-cleavage patterns. These findings strongly suggested that all isolates were genetically identical. The method was applied successfully to follow intra- and inter-individual spread. We demonstrated the transmission of one $S$. aureus strain between seven patients and its continuance for 1-2 weeks in two patients.

Reproducibility of the method and stability of the organisms examined are major factors for evaluating a typing system. We demonstrated genetic stability of $S$. aureus during 60 subcultures. Reproducibility of DNA extraction, restriction endonuclease digestion, electrophoretic separation on polyacrylamide gels, and silver staining was also good. SF-REA does not require expensive equipment, ultracentrifugation, time consuming agarose-

\section{REFERENCES}

1. Burnie JP, Matthews RC. Immunoblot analysis: a new method for fingerprinting hospital pathogens. J Immunol Methods 1987; 100: 41-46.

2. LeFebvre RB, Perng GC, Johnson RC. Characterization of Borrelia burgdorferi isolates by restriction endonuclease analysis and DNA hybridization. J Clin Microbiol 1989; 27: 636-639.

3. Collins DM, De Lisle GW. DNA restriction endonuclease analysis of Mycobacterium bovis and other members of the tuberculosis complex. J Clin Microbiol 1985; 21 : 562-564.

4. Grothues D, Koopmann U, Hardt $\mathrm{H}$ van der, Tümmler B. Genome fingerprinting of Pseudomonas aeruginosa indicates colonization of cystic fibrosis siblings with closely related strains. J Clin Microbiol 1988; 26: 19731977.

5. Kaper JB, Bradford HB, Roberts NC, Falkow S. Molecular epidemiology of Vibrio cholerae in the US Gulf coast. $J$ Clin Microbiol 1982; 16: 129-134.

6. Ketel RJ van. Similar DNA restriction endonuclease profiles in strains of Legionella pneumophila from different serogroups. J Clin Microbiol 1988; 26: 1838-1841.

7. Langenberg W, Rauws EAJ, Widjojokusumo A, Tytgat GNJ, Zanen HC van. Identification of Campylobacter pyloridis isolates by restriction endonuclease DNA analysis. J Clin Microbiol 1986; 24 : 414-417.

8. Poh CL, Ocampo JC, Sng EH, Bygdeman SM. Rapid insitu generation of DNA restriction endonuclease patterns for Neisseria gonorrhoeae. J Clin Microbiol 1989 27: 2784-2788.

9. Kristiansen BE, Sorensen B, Bjorvatn B et al. An outbreak of group $B$ meningococcal disease : tracing the causative strain of Neisseria meningitidis by DNA fingerprinting. J Clin Microbiol 1986; 23: 764-767.

10. Kuijper EJ, Oudbier JH, Stuifbergen WNHM, Jansz A, Zanen HC van. Application of whole-cell DNA restriction endonuclease profiles to the epidemiology of Clostridium difficile-induced diarrhea. J Clin Microbiol 1987; 25 : 751-753. gel electrophoretic techniques or blotting. Results can be achieved within $12 \mathrm{~h}$ from the point of cell harvest. Up to 20 samples can be processed easily in one working day. Therefore, SF-REA can support hospital infection control effectively.

Another advantage of this method is the stability of silver-stained polyacrylamide gels. They are stable for months. Original gels of different working periods can be compared directly. We conclude that SF-REA is a simple, rapid and accurate method for specifying the identity of $S$. aureus strains. It is especially useful for examining nosocomial outbreaks and person-to-person transmissions. The method is discriminatory, reproducible and suitable for routine laboratory use.

We thank P. Boomgaarden and C. Niehaus Rolf for excellent technical assistance.

11. Denning DW, Baker CJ, Troup NJ, Tompkins LS. Restriction endonuclease analysis of human and bovine group B streptococci for epidemiologic study. J Clin Microbiol 1989; 27: 1352-1356.

12. Renaud F, Freney J, Etienne J et al. Restriction endonuclease analysis of Staphylococcus epidermidis DNA may be a useful epidemiological marker. J Clin Microbiol 1988; 26: 1729-1734.

13. Jordens JZ, Hall LMC. Characterisation of methicillinresistant Staphylococcus aureus isolates by restriction endonuclease digestion of chromosomal DNA. J Med Microbiol 1988; 27 : 117-123.

14. Veraldo PE, Satta G. Staphylococcal diseases. In: Balows A, Hausler WJ, Ohashi M, Turano A (eds) Laboratory diagnosis of infectious diseases, principles and practice, vol 1. New York, Springer. 1988: 473-482.

15. DIN Deutsches Institut für Normung e. V.. DIN 58940(3): methods for the determination of the susceptibility of pathogenic bacteria (without mycobacteria) to chemotherapeutic substances; agar diffusion test. In: Medizinische Mikrobiologie, Normen und weitere Auflagen. Berlin, Beuth. 1987: 193-196.

16. Harstein AI, Morthland VH, Eng S, Archer GL, Schoenknecht FD, Rashad AL. Restriction enzyme analysis of plasmid DNA and bacteriophage typing of paired Staphylococcus aureus blood culture isolates. J Clin Microbiol 1989; 27 : 1874-1879.

17. Tsang VCW, Peralta JM, Simons AR, Enzyme-linked immunoelectrotransfer blot techniques (EITB) for studying the specificities of antigens and antibodies separated by gel electrophoresis. Methods in enzymology, vol. 92. New York, Academic Press. 1983: 377391.

18. McGowan JE, Terry PM, Huang TSR, Houk CL, Davies J. Nosocomial infections with gentamicin-resistant Staphylococcus aureus: plasmid analysis as an epidemiologic tool. J Infect Dis 1979; 140: 864-872.

19. Martin-Bourgon C. Phage typing of Staphylococcus aureus from cases of bacteraemia. J Hosp Infect 1985; 6: 429433. 
20. Khalifa KI, Heiba AA, Hancock G. Nontypeable bacteriophage patterns of methicillin-resistant Staphylococcus aureus involved in a hospital outbreak. J Clin Microbiol 1989; 27 : 2249-2251.

21. Archer GL, Mayhall CG. Comparison of epidemiological markers used in the investigation of an outbreak of methicillin-resistant Staphylococcus aureus infections. $J$ Clin Microbiol 1983; 18: 395-399.

22. Burnie JP, Matthews RC, Lee W, Murdoch D. A comparison of immunoblot and DNA restriction patterns in characterising methicillin-resistant isolates of Staphylococcus aureus. J Med Microbiol 1989; 29: 255-261. 